\title{
Characterization of alphabaculovirus: HearNPV-IIPR05 isolate infecting Helicoverpa armigera (Hubner) larvae
}

\author{
Sanjay M. Bandi ${ }^{*}$, P. S. Shanmugavadivel ${ }^{1}$, Lalit Kumar ${ }^{2}$ and A. Revanasidda ${ }^{1}$
}

\begin{abstract}
Background: The alphabaculoviruses are lethal pathogens of lepidopteran caterpillars including a polyphagous and globally recognized pest, Helicoverpa armigera (Hubner) infesting economically important agriculture crops worldwide. The biological and molecular characterizations of indigenous nucleopolyhedrovirus of the genus Alphabaculovirus isolated from H. armigera in chickpea fields are described.

Results: The virulence of virus isolate was tested in 3rd instar $\mathrm{H}$. armigera larvae, and $\mathrm{LC}_{50}$ (median lethal concentration) was estimated to be $2.69 \times 10^{4} \mathrm{OBs} \mathrm{ml}^{-1}$. The $\mathrm{ST}_{50}$ (median survival time) was 4 days post-inoculation, when the $3 r d$ instar $\mathrm{H}$. armigera larvae were inoculated by $\mathrm{OB}$ (occlusion body) concentration equivalent to $\mathrm{LC}_{90}$. An average incubation period of the virus isolate in 3rd instar ranged between 4 and 6 days post-inoculation. The OBs of a virus isolate appeared irregular in shape and variable in size with diameter ranging from 0.57 to $1.46 \mu \mathrm{m}$ on the longest edge and average of $1.071 \pm 0.068 \mu \mathrm{m}$ (mean \pm SE). On the basis of phylogenetic analysis of polh, pif-1, and lef-8 genes, the isolate was found to be a member of the genus Alphabaculovirus. The isolate showed a genetic affinity with species of group II Alphabaculoviruses and appeared to be a group II NPV.

Conclusions: On the basis of molecular phylogeny and associated host insect, this indigenous isolate was designated as HearNPV-IIPR05 isolate, which could be a potential candidate for the biological control of $\mathrm{H}$. armigera infesting legumes and other commercial crops.
\end{abstract}

Keywords: Alphabaculovirus, Nucleopolyhedrovirus, Helicoverpa armigera, Phylogeny, Virulence, Biological control

\section{Background}

The baculoviruses are regarded as potential biological control agents because of their safety to vertebrates, high pathogenicity, host-specificity, and ability to cause epizootics in the insect population. They have been reported worldwide from over 600 host species (Martignoni and Iwai 1986), mostly from the insect species of orders Lepidoptera, Diptera, and Hymenoptera (Herniou et al. 2012). On the basis of genome sequence analysis and associated arthropod host, 4 genera, viz., Alphabaculovirus, Betabaculovirus, Gammabaculovirus, and Deltabaculovirus, were recognized within the family

\footnotetext{
*Correspondence: sanjaysmb@gmail.com

${ }^{1}$ ICAR-Indian Institute of Pulses Research, Kanpur 208024, India

Full list of author information is available at the end of the article
}

Baculoviridae (Herniou et al. 2012). The genus Alphabaculovirus that included lepidopteran-specific nucleopolyhedroviruses (NPVs) is further classified into group I and group II NPVs, based on the presence of envelope fusion proteins in budded viruses, viz., GP64 and F protein, respectively (Lauzon et al. 2006).

Nearly 38 genes are reported to be conserved among all sequenced genomes of baculovirus till date, and these genes are assigned as core genes (Williams et al. 2016; Blissard and Theilmann 2018). Degenerate primers amplifying conserved genomic regions of a broad phylogenetic range of baculoviruses were used to study the relationship between viruses based on nucleotide variations. Oligonucleotides that amplify partial sequences of baculovirus core genes, polyhedrin encoding a major 
matrix protein of OBs and late expression factors (lef-8 and lef-9) encoding subunits of baculovirus RNA polymerase from various baculovirus genomes, were commonly used for characterization of baculovirus species (Herniou et al. 2003; Lange et al. 2004; Jehle et al. 2006b; Jose et al. 2013). Few of the genes coding for ODV envelope protein, per os infectivity factors (pif-1 and pif-2) mediating oral infectivity were also reported to be conserved in baculoviruses (Herniou et al. 2003; Ohkawa et al. 2005; Okano et al. 2006), and used for species discrimination.

Baculovirus isolates from diverse ecological regions differed in their biological traits (Erlandson et al. 2007; Ali et al. 2018) due to their evolution over a period of time and space. The variations in their biological traits in terms of pathogenesis, virulence, and speed of kill were reported among the distinct geographical isolates of baculovirus (Rabindra 1992). The genotypic variations within or between baculovirus populations have been reported. Alphabaculoviruses comprised of lepidopteranspecific NPVs isolated from the same host species in different geographical regions indicated heterogeneity in DNA profiles (Gettig and McCarthy 1982). The genetic variants isolated from single host insect differed in their phenotypic traits for pathogenicity and speed of kill (Murillo et al. 2006). The intraspecific genetic diversity among the 8 strains of $H$. armigera NPV (HearNPV) was identified (Figueiredo et al. 2009), and coexistence of genotypic variants is frequently reported within the natural baculovirus populations (Cory and Myers 2003). The NPVs isolated from Helicoverpa armigera (Hubner) in different locations exhibited significant variations in virulence measured in terms of median lethal concentration (Rabindra 1992). Hence, development of viral biocontrol agents involves selection of naturally occurring region-specific isolates and their virulence against local host-insect population for the effective management of associated host-insect pest.

In the present study, an indigenous baculovirus was isolated from naturally infected $H$. armigera larvae considering its adaptability to given set of climatic conditions of agroecosystem and virus-host interaction influencing characteristics of concentration-response and survival time of infected host. Biological activity, $\mathrm{OB}$ morphology, and phylogeny of 3 core genes (polh, pif-1, and $l e f-8)$ of a virus isolate were described.

\section{Methods}

Test insect

The culture of $H$. armigera used in this study was established in the laboratory from the field collected larval population. Larval colonies were provided by chickpeabased semi-synthetic diet as described by Nagarkatti and Satyaprakash (1974). The moths obtained from the field collected larvae were examined by mother moth examination method for every generation to obtain disease-free colony (FAO 2011). The abdominal content from the spent moths was excised and homogenized in sterilized water. A droplet was smeared on a slide and examined under light microscope $(\times 100)$ for the presence of disease-causing organisms including baculovirus. All the progenies from infected moths, if any, were discarded. The eggs and larvae obtained from the healthy moths were raised carefully. The disease-free colonies were reared for 3 successive generations under controlled conditions $\left(26 \pm 1{ }^{\circ} \mathrm{C}\right.$ and $\left.70 \pm 5 \% \mathrm{RH}\right)$ and a photoperiod (14:10 h light:dark) in BOD incubator, before being used for virus multiplication.

\section{Virus isolate}

The virus was isolated from naturally infected larvae of $H$. armigera collected from chickpea fields in New Research Farm, IIPR, Kanpur (India) $\left(26^{\circ} 31^{\prime} 13.41^{\prime \prime} \mathrm{N}\right.$; $\left.080^{\circ} 14^{\prime} 49.69^{\prime \prime} \mathrm{E}\right)$ on the basis of typical baculovirusinduced symptoms described by Whitlock (1974). The presence of OBs of virus in the cadavers was confirmed by light microscopy. The virus was propagated in the healthy early instar ( 3rd instar) larvae of $H$. armigera by establishing infection with $\mathrm{OB}$ contaminated artificial diet, and cadavers exhibiting baculovirus symptoms were harvested for extraction of OBs.

\section{Purification of viral occlusion bodies}

The OBs from the cadavers were recovered by 2 differential cycles of centrifugation following the procedures of Rabindra et al. (2003) with slight modifications as described below. Infected insect cadavers were homogenized in a small volume of sodium dodecyl sulfate (SDS) $(0.1 \%)$ and maintained overnight at room temperature. The homogenate was filtered through 4 layers of muslin cloth to remove the insect tissue debris. The filtrate was initially centrifuged at $500 \mathrm{rpm}$ for $1 \mathrm{~min}$ to remove larger contaminants, and supernatant was again spun at $5000 \mathrm{rpm}$ twice for $15 \mathrm{~min}$ each to pellet the occlusion bodies. The pellet was washed 3 times by distilled water and re-suspended in double-distilled water, and aqueous suspension of virus was preserved at $\leq 4{ }^{\circ} \mathrm{C}$. The OBs were enumerated, using improved Neubauer's Hemocytometer (0.1 mm depth) (Fein-Optik Jena, Germany) at $\times 400$ magnification for bioassay studies.

\section{Electron microscopy}

Morphology of the purified OBs extracted from individual larvae was studied under scanning electron microscope (SEM) (Model: FEI Quanta 250, The Netherlands) and transmission electron microscope (TEM) (Model: Jeol JEM 1400, Japan) at EM Unit-SAIF, CSIR-CDRI, Lucknow (India), and photographed at different 
magnifications. The shape and average size on the longest edge of OBs were recorded.

\section{Virus bioassay}

Biological activity of the virus isolate was tested in 3rd instar larvae of $H$. armigera infected per os by "diet surface contamination" method (Eberle et al. 2012). To study the concentration-mortality response, 6 concentrations ranging between $3 \times 10^{6}$ and $3 \times 10^{2} \mathrm{OBs} \mathrm{ml}^{-1}$ were prepared. About $50 \mu \mathrm{l}$ of viral suspension was dispensed over the surface of chickpea-based semisynthetic diet and spread uniformly over the surface using blunt glass rod, which was allowed to dry for about $10 \mathrm{~min}$. Each treatment consisted of 15 prestarved larvae (for $4 \mathrm{~h}$ ) including the untreated control. The larvae were maintained individually, and each test was repeated thrice. The bioassay was carried out under controlled conditions at $26 \pm 1{ }^{\circ} \mathrm{C}$ and $70 \pm 5 \% \mathrm{RH}$. Observations on mortality were recorded at $24 \mathrm{~h}$ interval starting from 4th day post-inoculation, and viral infection was confirmed by smear test. The mortality data were corrected depending upon the mortality in the control following Abbott's formula (Abbott 1925). Any assays with more than $10 \%$ larval mortality in controls were rejected. The corrected mean larval mortality for each concentration was subjected to probit analysis (Finney 1971) for determination of median lethal concentration $\left(\mathrm{LC}_{50}\right)$ using SPSS statistical program 25.

The time-mortality response was studied in the 3rd instar larvae of $H$. armigera that was inoculated at 2 concentrations representing $\mathrm{LC}_{50}$ and $\mathrm{LC}_{90}$ previously determined in concentration-mortality assay. A group of 15 larvae, which were pre-starved for $4 \mathrm{~h}$, were inoculated by $50 \mu$ of viral suspension and incubated as described under the concentration-mortality assay. Larvae in controls that had not consumed viral inoculum were incubated at similar conditions, and larval mortality was recorded at every $24 \mathrm{~h}$ interval for 10 days. Time-mortality results of individual larvae that died due to viral infection were subjected to Kaplan-Meier estimate for survival analysis using SPSS statistical program 25. A test for significant variation between survival curves was performed by a $\log$ rank test (level of significance, $P \leq 0.05$ ).

\section{Phylogenetic analysis of polh, pif-1, and lef-8 genes}

Viral DNA was extracted from purified $O B$ suspension according to the procedure described by Woo (2001) with some requisite modifications described hereafter. The purified OBs were re-suspended in $0.1 \mathrm{M}$ sodium carbonate solution. About $0.5 \mathrm{mg} \mathrm{m}^{-1}$ of proteinase $\mathrm{K}$ and $1 \%$ SDS was added to the final suspension and incubated at $37^{\circ} \mathrm{C}$ for overnight. This was followed by extraction with phenol:chloroform:isoamylalcohol solution (25:24:1). The DNA was precipitated in ice cold absolute ethanol, and the pellet was re-suspended in TE buffer (10 mM Tris- $\mathrm{HCl}, 1 \mathrm{mM}$ EDTA, pH 8.0). The quality of extracted DNA was confirmed by electrophoresing in $0.8 \%$ agarose gel. The coding region of core genes, polyhedrin (polh), per os infectivity factor (pif-1), and late expression factor (lef-8), was targeted to amplify using specific primers. The primer pairs targeting polh and pif1 genes were synthesized as described previously (Ashika et al. 2017). A set of 3 primer pairs amplifying $2.2 \mathrm{~kb}$ of lef8 gene from HearNPV were designed with published sequences available in the GenBank database of National Center for Biotechnology Information (NCBI) using Primer3 tool (Untergasser et al. 2012) (Table 1). Each polymerase chain reaction (PCR) mixture consisted of $50 \mathrm{ng}$ template DNA sample, $1 \mathrm{U}$ of Taq DNA polymerase, 10× Taq buffer, $2.5 \mathrm{mM} \mathrm{MgCl}_{2}, 2.5 \mathrm{mM}$ of dNTP mix $\left(\mathrm{Genei}^{\mathrm{TM}}\right)$, and $5 \mu \mathrm{l}$ of each forward and reverse primer in a final volume of $50 \mu \mathrm{l}$ reaction mixture. Amplification of partial sequences of polh, pif-1, and lef-8 genes was done using BioRad Thermal Cycler with an amplification program as follows: initial denaturation at $95^{\circ} \mathrm{C}$ for $5 \mathrm{~min}$, followed by 35 cycles of denaturation at $95^{\circ} \mathrm{C}$ for $30 \mathrm{~s}$, annealing at 48 to $60^{\circ} \mathrm{C}$ (annealing temperature varied for primer sets based on $\mathrm{Tm}$ value and given in Table 1) for $30 \mathrm{~s}$ and extension at $72{ }^{\circ} \mathrm{C}$ for $45 \mathrm{~s}$, final extension at $72{ }^{\circ} \mathrm{C}$ for $10 \mathrm{~min}$, and storage at $4{ }^{\circ} \mathrm{C}$ till further usage. The amplicons were checked in $2 \%$ agarose gel for their target size amplification.

The PCR amplicons were purified prior to sequencing and sequenced using both forward and reverse primers by Genei Laboratories (Bengaluru) and Bioserve Biotechnologies (Hyderabad). For each gene, 3 independent amplification and sequencing reactions were performed. The sequence data of polh, pif-1, and lef-8 were assembled into contigs by using contig assembly module present in the BioEdit Software (Hall 1999). The sequences obtained in this study were subjected to similarity search using NCBI BLAST programs. The sequences generated were used to determine the phylogenetic relationships between the isolate under study and other baculovirus species recognized by the International Committee on Taxonomy of Viruses (ICTV). The deduced amino acid sequences of core genes from the isolate and GenBank retrieved sequences were aligned by MUSCLE using MEGA6 software suite. Phylogenetic analysis of aligned amino acid sequences was performed to study the taxonomic relationship of the isolate under study using MEGA6 tool, following UPGMA method (Tamura et al. 2013) with bootstrap of 1000 replications.

\section{Results}

\section{Virus isolate}

The virus isolated from the naturally infected $H$. armigera larvae collected from chickpea plant manifested typical signs of virus infection (Fig. 1a). The presence of 
Table 1 Details of the baculovirus target core genes, primer sequences, and annealing temperature for amplification of DNA fragments

\begin{tabular}{|c|c|c|c|}
\hline Target genes & Primer sequence & Amplicon size (bp) & Annealing temperature $\left({ }^{\circ} \mathrm{C}\right)$ \\
\hline \multirow[t]{2}{*}{ Polyhedrin (polh) } & F: 5'-ACTCGTTACAGTTACAGCCCTACT-3' & 659 & 54 \\
\hline & R: 5'-CAGTGTATAGCGGAGCGTCA-3' & & \\
\hline \multirow[t]{2}{*}{ Per os infectivity factor-1 (pif-1) } & F: 5'-CCGCTACCAATTCACGAAG-3' & 1392 & 48 \\
\hline & R: 5'-TCATGTGTACGTGGAATAATTGG-3' & & \\
\hline \multirow[t]{6}{*}{ Late expression factor-8 (lef-8) } & F: 5'-GACGTGATTGCCGATTTC-3' & 940 & 58 \\
\hline & R: 5'-TTTCAATGTTGTTGTTGCTG-3' & & \\
\hline & F: 5'-GATCGTAGACACTATAGTCAATGG-'3' & 855 & 60 \\
\hline & R: 5'-GCGTTTTTCAAATTGGTC-3' & & \\
\hline & F: 5'-CAATAATCGAAAAGGACACAG-3' & 949 & 58 \\
\hline & R: 5'-TTGAAAATATTATCGGGAGTG-3' & & \\
\hline
\end{tabular}

polyhedral occlusion bodies was detected in the discharged body fluid of cadavers under phase-contrast light microscope at $\times 400$ magnification (Fig. 1b). These POBs exhibited Brownian movement in wet mounts. This isolate of virus established lethal infection when healthy and early instar larvae of $H$. armigera were fed with purified $\mathrm{OB}$ contaminated semi-synthetic diet in the laboratory (Fig. 1c).

\section{Virulence of the virus isolate}

Biological activity of the virus isolate was determined by measuring the concentration-mortality response $\left(\mathrm{LC}_{50}\right)$ of 3rd instar larvae of $H$. armigera. The isolate of virus induced lethal infection in the inoculated 3rd instar larvae within 5 or rarely 6 days post-inoculation. Untreated larvae developed normally until pupation. The $\mathrm{LC}_{50}$ value of virus isolate was estimated to be $2.69 \times 10^{4} \mathrm{OBs}$ $\mathrm{ml}^{-1}$ (95\% fiducial limits, $2.83 \times 10^{3}$ to $\left.2.34 \times 10^{5}\right)$. The slope of the concentration-response line was $0.38 \pm 0.12$ $\left(x^{2} 0.45\right)$ (Fig. 2).

To test the time response of $H$. armigera, a survival time analysis was conducted on 3rd instar larvae inoculated with
OBs at concentrations representing $\mathrm{LC}_{50}$ and $\mathrm{LC}_{90}$ values, in contrast to full-range bioassay. The survival rate of larvae differed significantly at different concentrations by log rank test (log rank test; $\left.X^{2}=4.32 ; P \leq 0.05\right)$, and 2 patterns in KaplanMeier survival curves were visible (Fig. 3). The larval mortality did not occur before $3 \mathrm{dpi}$, and probability of survival started to decline at $3 \mathrm{dpi}$ for both concentrations tested. The survival rate for larvae declined gradually, irrespective of $\mathrm{OB}$ concentrations received by larvae. The median survival time $\left(\mathrm{ST}_{50}\right)$ was 4 and 6 dpi for larvae receiving $\mathrm{OB}$ concentration equivalent to $\mathrm{LC}_{90}$ and $\mathrm{LC}_{50}$ values, respectively, which differed significantly according to log rank test $(P=0.038)$. The survival rate of $H$. armigera larvae was $15 \pm 0.08$ and $40 \pm 0.11 \%$ at $\mathrm{LC}_{90}$ and $\mathrm{LC}_{50}$, respectively.

\section{OB morphology}

A distinguishing feature of baculoviridae is the presence of OBs which are critical for transmission of virus in host insects and survival of the virus outside the host (Blissard and Rohrmann 1990). In the present study, the OBs of virus isolate exhibited irregular shape, a typical character of OBs of NPV belonging to Alphabaculovirus.

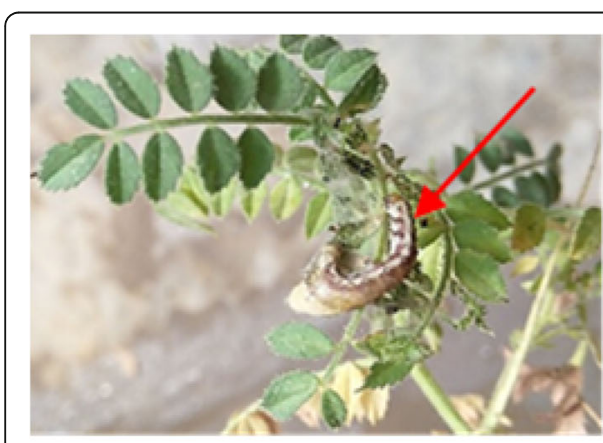

(a)

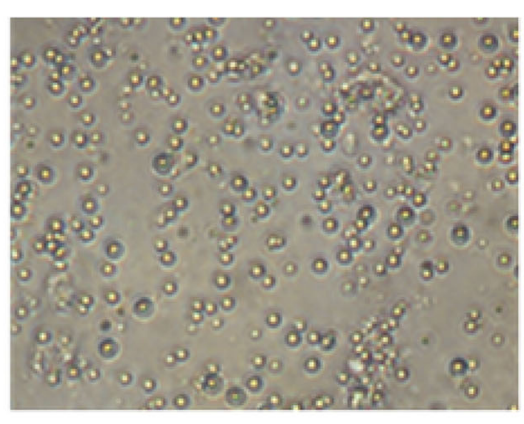

(b)

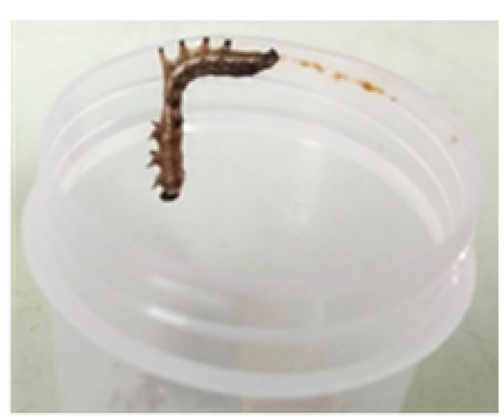

(c)

Fig. 1 a Helicoverpa armigera larvae on chickpea showing baculovirus infection. b Phase-contrast image $(\times 400)$ of baculovirus OBs. c Virosed larvae of Helicoverpa armigera exhibiting symptoms of nucleopolyhedrovirus (NPV) infection 


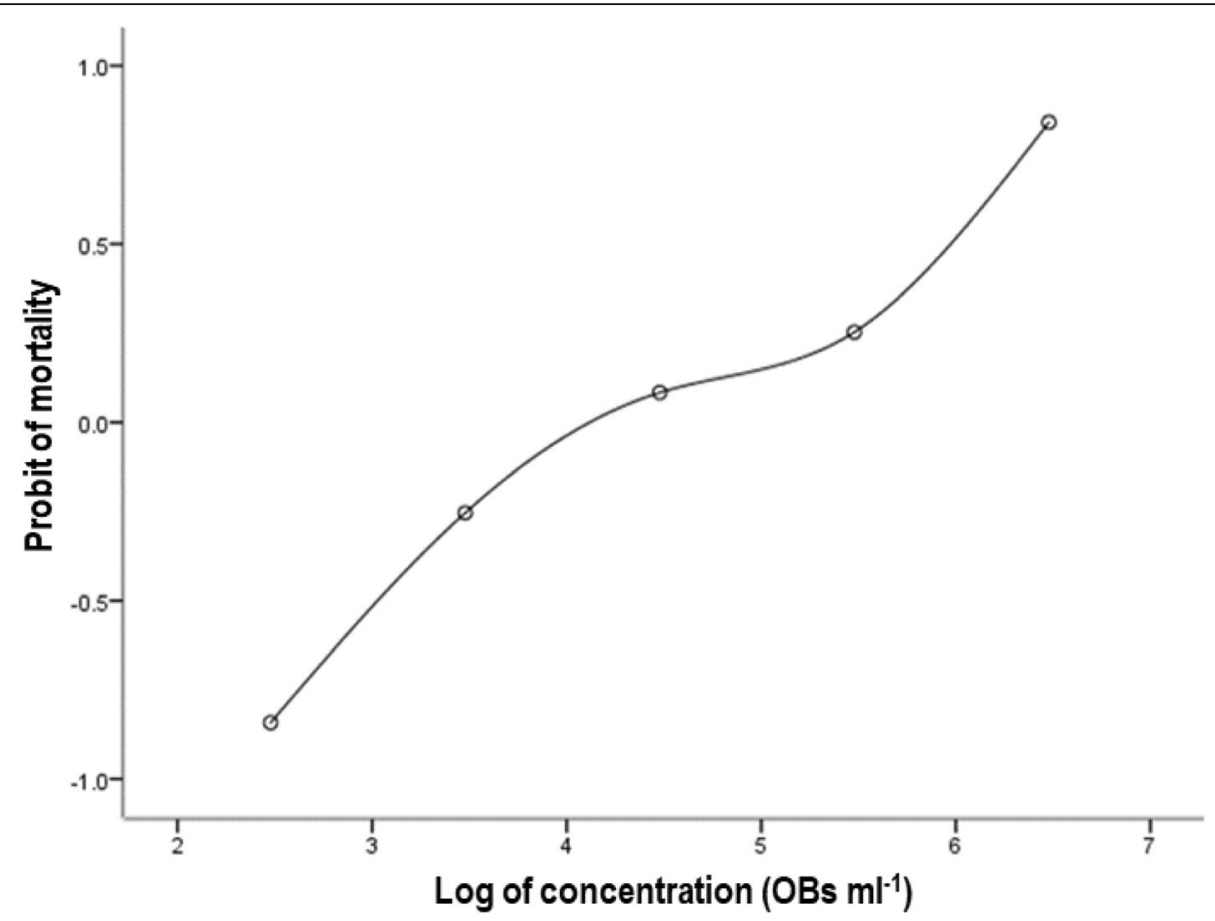

Fig. 2 Log (conc.)-probit mortality curve for Helicoverpa armigera larvae at different occlusion body (OB) concentrations

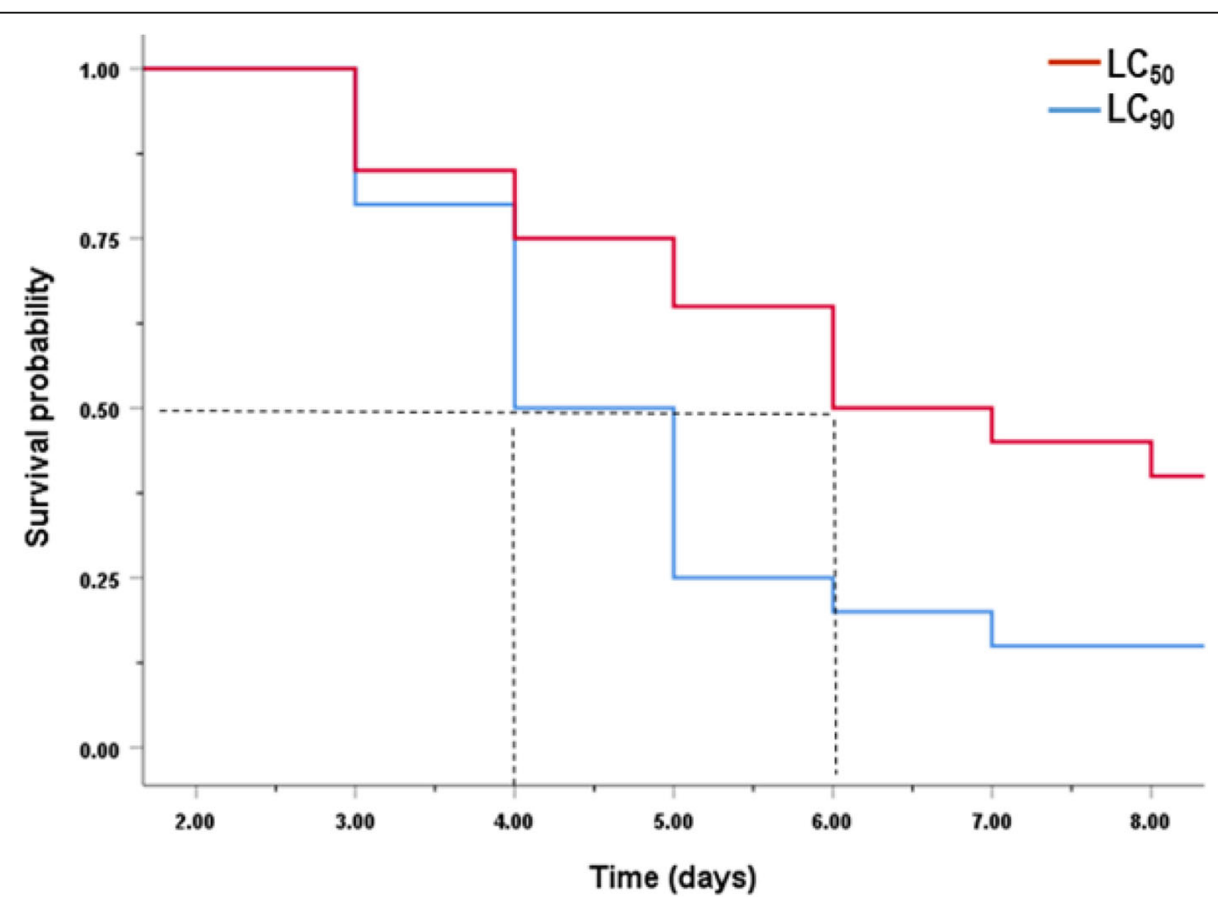

Fig. 3 Survival function of Helicoverpa armigera larvae at different occlusion body (OB) concentrations 


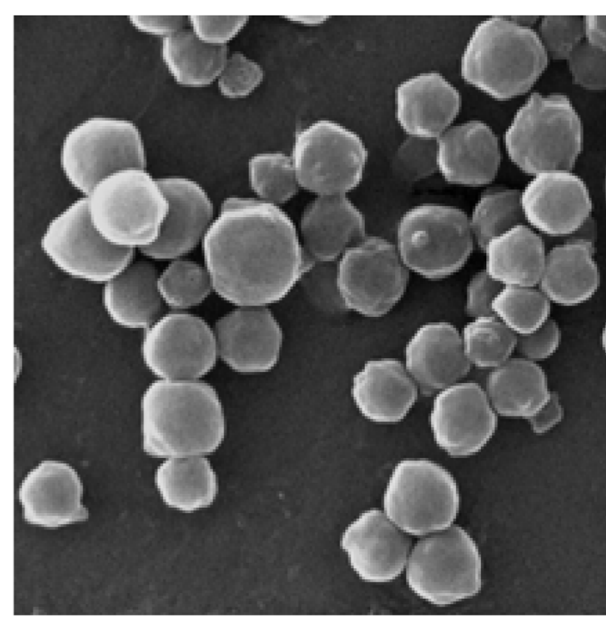

(a)

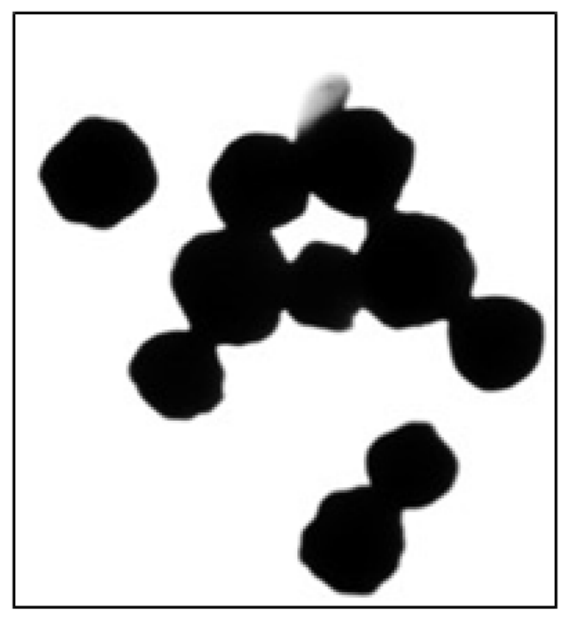

(b)

Fig. 4 a SEM and $\mathbf{b}$ TEM micrographs of viral occlusion bodies (OBs)

The OBs in SEM micrograph measured between 0.57 and $1.46 \mu \mathrm{m}$ in diameter on the longest edge, with an average of $1.071 \pm 0.068 \mu \mathrm{m}$ (mean $\pm \mathrm{SE}, n=20)$ (Fig. 4).

\section{Phylogeny of polh, pif-1, and lef-8 genes}

Nucleotide sequences of baculovirus core genes, polh, pif-1, and lef-8, were generated to determine the taxonomic position of virus isolate. PCR amplification of polh, pif-1, and lef-8 genes from the present isolate using gene-specific primers resulted in amplicons of 596, 1375, and $2199 \mathrm{bp}$ size, respectively (Fig. 5). The partial nucleotide sequences of 3 genes from the present isolate were submitted in GenBank (Accession Numbers MN603765, MN603764, and MN603763, respectively). The amplicon size obtained in the present study for each gene corroborated with published reports (Jose et al. 2013; Ashika et al. 2017). The full-length ORF of completely sequenced lef- 8 genes varied between 2484 and 2757 bp (Pang et al. 2001).

The top matches of BLASTx queries for the present isolate were species of alphabaculovirus infecting host

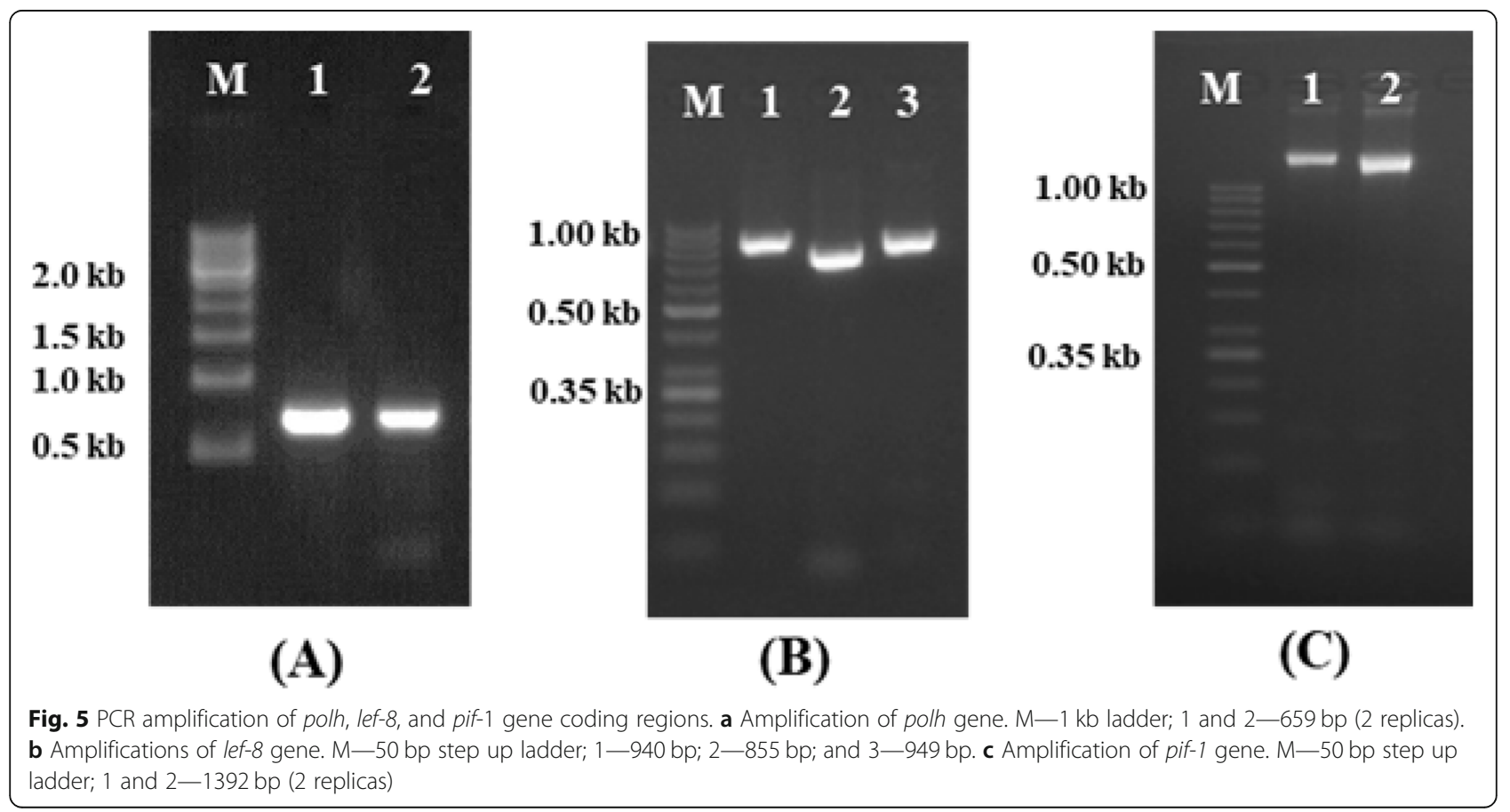


species of the genus Helicoverpa, indicating genetic closeness with these viruses. The polh gene sequence exhibited more than $99 \%$ nucleotide identity with 17 isolates of HearNPV and 6 isolates of $H z \mathrm{NPV}$ available in GenBank. The sequences of lef-8 revealed more than 99\% homology with 16 isolates of HearNPV and 4 isolates of HzNPV. The pif-1 gene analysis revealed greater than $99 \%$ sequence identity with 8 isolates of HearNPV and 3 isolates of $H z \mathrm{NPV}$. All the GenBank isolates exhibiting maximum identity with our isolate belonged to the genus Alphabaculovirus.

The genetic relatedness of the isolate was determined by phylogenetic analysis of concatenated amino acid sequences from 3 core genes (polh, pif-1, and lef-8) of baculoviruses, following UPGMA analysis (Fig. 6). The phylogenetic tree of representative ICTV recognized baculovirus species and our isolate formed 4 distinct clades, viz., Alphabaculovirus, Betabaculovirus, Gammabaculovirus, and Deltabaculovirus, with high bootstrap support and two sub-groups (group I and II NPVs) within Alphabaculovirus. The UPGMA tree of concatenated sequences placed our isolate in a clade with ICTV recognized NPV species belonging to the genus Alphabaculovirus and appeared to be closely related with members of alphabaculovirus. Phylogenetic analysis of sequences further positioned the isolate among the species of group II NPVs. Within this group, the obtained isolate clustered with two NPV species infecting $H$. armigera belonging to lepidopteran family Noctuidae (with bootstrap support of 100\%).

\section{Discussion}

The virus isolate established lethal infection in the healthy larvae of $H$. armigera when fed with purified $O B$ contaminated semi-synthetic diet. The diseased larvae manifested typical signs of baculovirus infection. Similar symptomatology was documented by Whitlock (1974) and Rowley et al. (2011) in NPV infected H. armigera larvae.

Survival time and proportion of response in treated insects are critical parameters to assess the effectiveness of the virus isolate (van Beek et al. 1988). The average incubation period of virus in 3rd instar larvae was about 4 to 6 dpi. Whitlock (1974) stated 6-7 or rarely 4-9 days of incubation period in Heliothis NPV. The speed of killing a host insect is eventually an estimate of the virulence of virus. Hughes et al. (1983) noted mean survival time ranging from 77.8 to $116.6 \mathrm{~h}$ for $H$. zea infected with NPV of different country of origin. The survival time and survival function of $H$. armigera larvae were decreased at the higher $\mathrm{OB}$ inoculums. Previous studies reported a decrease in larval median survival time of Heliothis zea (van Beek et al. 1988) and H. armigera (Dasgupta et al. 2016) with increase in concentration of virus inoculums. The small slope value of concentration-response line for isolate indicated a great variability in response of larvae

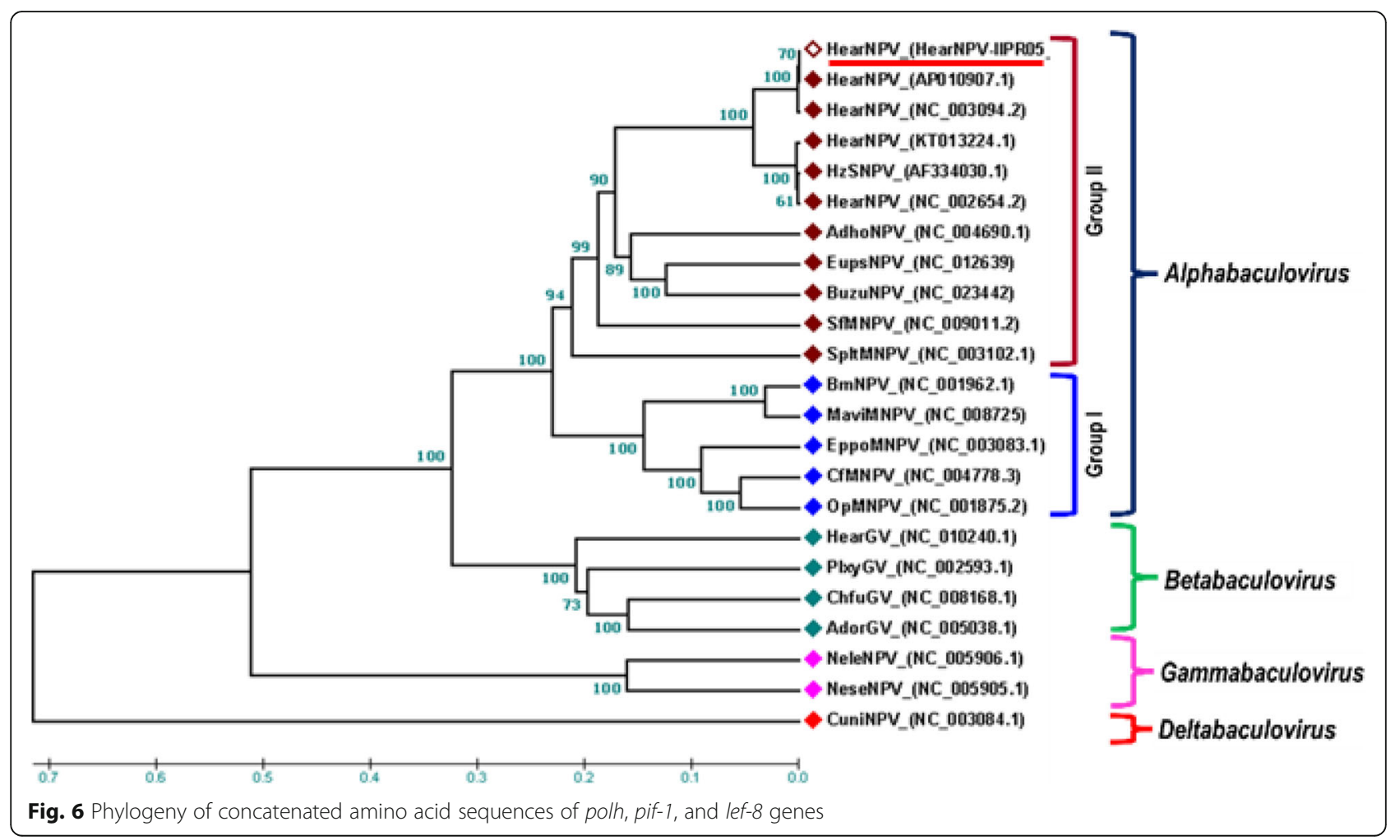


within the population in the rate of disease progression (Hughes et al. 1983; Teakle et al. 1986). Differences in biological activity were earlier reported among the baculovirus isolates from distinct geographical regions; however, isolates had overlapping fiducial limits of $\mathrm{LC}_{50}$ (Rabindra 1992; Somasekhar et al. 1993; Geetha and Rabindra 1999). Shapiro and Ignoffo (1970) noticed 56fold differences in concentration-mortality response among the 34 Heliothis NPV isolates. Hence, the local geographical strain of baculovirus is always preferred due to its adaptability to local environmental conditions and efficacy under a given set of climatic conditions in an agroecosystem. It is well recognized that the geographic origins of both virus and its host insect can affect their interactions particularly the characteristics of concentration-response and survival time of infected host insect (Milks 1997). The difference in virulence among the strains of baculoviruses was reported to be attributed to structure of the virus and its genetic composition (Escribano et al. 1999).

In the present study, the irregularly spherical OBs and their variable diameter confirmed to be of NPVs rather than GVs. Previous investigations on OB morphology had revealed the similar reports. Hamm and Young (1974) noticed the variation in size and shape of polyhedral inclusion bodies of NPV from Heliothis zea. The OBs in the Baculoviridae family measured about 0.15$5 \mu \mathrm{m}$ (Harrison et al. 2018). The OBs from virosed $H$. armigera were observed irregular, and diameter ranged between 0.5 and $2.5 \mu \mathrm{m}$ (Kumar et al. 2011) with a mean diameter of 0.89 (Jacob and Subramanian 1972) and $1.35 \mu \mathrm{m}$ (Sudhakar and Mathavan 1999).

The polh, pif-1, and lef-8 phylogeny strongly suggested that this isolate was found to be a species of group II Alphabaculovirus. The present results are in concordance with published reports, wherein the viruses infecting caterpillars of Noctuidae family were placed in group II NPVs on the basis of lef-8, lef-9, and polh gene phylogeny (Herniou et al. 2004; Lange et al. 2004; Jehle et al. 2006a, b). The amino acid-based phylogenetic analysis of baculovirus core genes is reported to be more consistent and robust than individual genes (Harrison et al. 2008). The polyhedrin was the first baculovirus gene ever sequenced and one of the most conserved genes of lepidopteran-specific baculoviruses, and sequence data for this gene are available for a large number of baculoviruses hence widely used in phylogenetic analysis (Lange et al. 2004). Pif-1 gene was also reported to be conserved in baculoviruses (Ohkawa et al. 2005). Similarly, lef-8 gene was identified in all sequenced baculoviruses (Herniou et al. 2003). Baculovirus genomics provided an approach for rapid and reliable identification of virus isolates (Herniou et al. 2001). Degenerate nucleotides from comparative analysis of lepidopteran- specific baculovirus genome sequences especially at gene levels such as $l e f-8$, lef-9, and polh were well utilized to demarcate baculovirus species (Jehle et al. 2006a, b) and to classify the baculoviruses.

\section{Conclusion}

In the present study, an indigenous alphabaculovirusHearNPV-IIPR05, specific to $H$. armigera, was isolated and identified. The molecular phylogeny of baculovirus core genes (polh, pif-1, and lef-8) indicated that the isolate belongs to the genus Alphabaculovirus of Baculoviridae. This isolate could be further utilized for the development of bio-pesticide for managing the $H$. armigera in legumes and other important host crops.

\section{Abbreviations}

NPV: Nucleopolyhedrovirus; OBs: Occlusion bodies; GV: Granulovirus; LC: Lethal concentration; ST: Survival time; HearNPV: Helicoverpa armigera NPV; Polh: Polyhedrin; Pif: Per os infectivity factor; Lef: Late expression factor; ICAR: Indian Council of Agricultural Research; IIPR: Indian Institute of Pulses Research; SDS: Sodium dodecyl sulfate; SEM: Scanning electron microscope; TEM: Transmission electron microscope; dpi: Day post-inoculation; PCR: Polymerase chain reaction; NCBI: National Center for Biotechnology Information; BLAST: Basic Local Alignment Search Tool; ICTV: International Committee on Taxonomy of Viruses

\section{Acknowledgements \\ The authors are thankful to the Director, ICAR-IIPR, Kanpur (India), for provid- ing facilities. We also acknowledge Dr. Kalyan Mitra (Principal Scientist) for providing SEM and TEM facilities at Electron Microscopy Unit (Sophisticated Analytical Instrument Facility) of CSIR-CDRI, Lucknow (India). Authors express special thanks to Dr. S.K. Jalali (Former Principal Scientist and Head, Division of GR, ICAR-NBAIR, Bengaluru, India) for his valuable inputs during the study and critical review of the manuscript.}

\section{Authors' contributions}

SMB designed the study, conducted the experiments, and prepared the manuscript. PSS, LK, and R contributed in conducting the experiments and preparation of manuscript. All the authors read and approved the final manuscript for publication.

\section{Funding}

Not applicable.

\section{Availability of data and materials}

The datasets used and/or analyzed during the current study are available from the corresponding author on reasonable request.

Ethics approval and consent to participate

Not applicable.

\section{Consent for publication}

Not applicable.

\section{Competing interests}

The authors declare that they have no competing interests.

\section{Author details}

${ }^{1}$ ICAR-Indian Institute of Pulses Research, Kanpur 208024, India. ${ }^{2}$ ICAR-Indian Institute of Farming Systems Research, Modipuram 250110, India.

Received: 14 September 2020 Accepted: 8 January 2021

Published online: 15 January 2021

\section{References}

Abbott WS (1925) A method of computing the effectiveness of an insecticide. J Econ Entomol 18:265-267 
Ali G, Abma-Henkens MHC, van der Werf W, Hemerik L, Vlak JM (2018) Genotype assembly, biological activity and adaptation of spatially separated isolates of Spodoptera litura nucleopolyhedrovirus. J Invertebr Pathol 153:20-29

Ashika TR, Ojha R, Jalali SK, Shivalingaswamy TM (2017) Comparative study of hot-start PCR characterized species specific conserved gene regions of a biocontrol agent Helicoverpa armigera nucleopolyhedrovirus with its whole genome. J Entomol Zool Stud 5(4):512-519

Blissard GW, Rohrmann GF (1990) Baculovirus diversity and molecular biology. Annu Rev Entomol 35:127-155

Blissard GW, Theilmann DA (2018) Baculovirus entry and egress from insect cells. Annu Rev Virol 5:113-139

Cory JS, Myers JH (2003) The ecology and evolution of insect baculoviruses. Annu Rev Ecol Evol Syst 34:239-372

Dasgupta S, Singh SR, Das S, Pathak SK, Bhola RK (2016) Molecular detection and pathogenicity of a nucleopolyhedrovirus isolated from looper caterpillar (Hyposidra talaca), a tea pest. 3-Biotech 6(2):245

Eberle KE, Wennmann JT, Kleespies RG, Jehle JA (2012) Basic techniques in virus technology. In: Lacey LA (ed) Manual of techniques in invertebrate pathology, 2nd edn. Academic Press, Cambridge, pp 15-74

Erlandson M, Newhouse S, Moore K, Janmaat A, Myers J, Theilmann D (2007) Characterization of baculovirus isolates from Trichoplusia ni populations from vegetable greenhouses. Biol Control 41:256-263

Escribano A, Williams T, Goulson D, Cave RD, Chapman JW, Caballero P (1999) Selection of a nucleopolyhedrovirus for control of Spodoptera frugiperda (Lepidoptera: Noctuidae): structural, genetic and biological comparison of four isolates from the Americas. J Econ Entomol 92(5):1079-1085

FAO (2011) The Helicoverpa armigera NPV production manual (Grzywacz D, Rabindra RJ, Brown M, Jones KA, Parnell M). Retrieved from: http://www.fao. org/docs/eims/upload/aggrotech/2011/HaNPVmanual-pt1.pdf on 03 Mar 2019

Figueiredo E, Munoz D, Murillo R, Mexia A, Caballero P (2009) Diversity of Iberian nucleopolyhedrovirus wild-type isolates infecting Helicoverpa armigera (Lepidoptera: Noctuidae). Biol Control 50:43-49

Finney DJ (1971) Probit analysis. Cambridge University Press, Cambridge, p 333

Geetha N, Rabindra RJ (1999) Genetic variability and comparative virulence of some geographic isolates of nuclear polyhedrosis virus of Helicoverpa armigera Hub. In: Ignacimuthu S, Sen A, Janarthana S (eds) Biotechnological application for integrated pest management. Oxford and IBH Publ. Co. Pvt. Ltd., New Delhi, pp 65-78

Gettig RG, McCarthy WJ (1982) Genotypic variation among wild isolates of Heliothis spp. nuclear polyhedrosis viruses from different geographic regions. J Virol 43:174-181

Hall TA (1999) BioEdit: a user-friendly biological sequence alignment editor and analysis program for Windows 95/98/NT. Nucleic Acid Symposium Series No. 41:95-98.

Hamm JJ, Young JR (1974) Mode of transmission of nuclear-polyhedrosis virus to progeny of adult Heliothis zea. J Invertebr Pathol 24:70-81

Harrison RL, Herniou EA, Jehle JA, Theilmann DA, Burand JP, Becnel JJ, Krell PJ, van Oers MM, Mowery JD, Bauchan GR (2018) ICTV Report Consortium-2018. ICTV virus taxonomy profile: Baculoviridae. J Gen Virol 99:1185-1186

Harrison RL, Puttler B, Popham HJR (2008) Genomic sequence analysis of a fastkilling isolate of Spodoptera frugiperda multiple nucleopolyhedrovirus. J Gen Virol 89:775-790

Herniou EA, Arif BM, Becnel JJ, Blissard GW, Bonning B, Harrison R, Jehle JA, Theilmann DA, Vlak JM (2012) Family: baculoviridae. In: Andrew MQ, Lefkowitz KE, Michael JA, Eric BC (eds) Virus taxonomy-ninth report of the International Committee on Taxonomy of Viruses 163-173, p 1327

Herniou EA, Luque T, Chen X, Vlak JM, Winstanley D, Cory JS, O'Reilly DR (2001) Use of whole genome sequence data to infer baculovirus phylogeny. J Virol 75:8117-8126

Herniou EA, Olszewski JA, Cory JS, O'Reilly DR (2003) The genome sequence and evolution of baculoviruses. Annu Rev Entomol 48:211-234

Herniou EA, Olszewski JA, O'Reilly DR, Corey JS (2004) Ancient coevolution of baculoviruses and their insect hosts. J Virol 78(7):3244-3251

Hughes PR, Getting RR, McCarthy WJ (1983) Comparison of the time-mortality response of Heliothis zea to 14 isolates of Heliothis nuclear polyhedrosis virus. J Invertebr Pathol 41:256-261

Jacob A, Subramanian TR (1972) Nuclear polyhedrosis on some Lepidoptera. Curr Sci 4:536
Jehle JA, Blissard GW, Bonning BC, Cory JS, Herniou EA, Rohrmann GF, Theilmann DA, Thiem SM, Vlak JM (2006a) On the classification and nomenclature of baculoviruses: a proposal for revision. Arch Virol 151(7):1257-1266

Jehle JA, Lange M, Wang H, Hu Z, Wang Y, Hauschild R (2006b) Molecular identification and phylogenetic analysis of baculoviruses from Lepidoptera. Virology 346:180-193

Jose A, Jalali SK, Shivalingaswamy TM, Krishna Kumar NK, Bhatnagar R, Bandyopadhyay A (2013) Molecular characterization of nucleopolyhedrovirus of three lepidopteran pests using late expression factor-8 gene. Indian J Virol 24(1):59-65

Kumar SC, Rao GVR, Sireesha K, Kumar PL (2011) Isolation and characterization of baculoviruses from three major lepidopteran pests in the semi-arid tropics of India. Indian J Virol 22(1):29-36

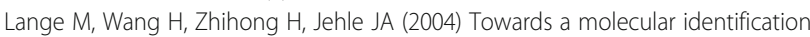
and classification system of lepidopteran-specific baculoviruses. Virology 325 : 36-47

Lauzon HAM, Garcia-Maruniak A, Zanotto PMA, Clemente JC, Herniou EA, Lucarotti CJ, Arif BM, Maruniak JE (2006) Genomic comparison of Neodiprion sertifer and Neodiprion lecontei nucleopolyhedron viruses and identification of potential hymenopteran baculovirus specific open reading frames. J Gen Virol 87:1477-1489

Martignoni ME, Iwai PJ (1986) A catalogue of viral diseases of insects, mites, and ticks, 4th edn. Gen. Tech. Rep. PNW-195. US Department of Agriculture, Forest Service, Pacific Northwest Research Station, Portland, p 51

Milks LC (1997) Comparative biology and susceptibility of cabbage looper (Lepidoptera: Noctuidae) lines to a nuclear polyhedrosis virus. Environ Entomol 26:839-848

Murillo R, Elvira S, Munoz D, Williams T, Caballero P (2006) Genetic and phenotypic variability in Spodoptera exigua nucleopolyhedrovirus isolates from greenhouse soils in southern Spain. Biol Control 38:157-165

Nagarkatti S, Satyaprakash (1974) Rearing Heliothis armigera (Hub.) on artificial diet, vol 17. Technical Bulletin, Commonwealth Institute of Biological Control, Bangalore, pp 169-173

Ohkawa T, Washburn JO, Sitapara R, Sid E, Volkman LE (2005) Specific binding of Autographa californica M nucleopolyhedrovirus occlusion-derived virus to midgut cells of Heliothis virescens larvae is mediated by products of pif genes Ac119 and AC022 but not by Ac115. J Virol 79(24):15258-15264

Okano K, Vanarsdall AL, Mikhailov VS, Rohrmann GF (2006) Conserved molecular systems of the Baculoviridae. Virology 344:77-87

Pang Y, Yu J, Wang L, Hu X, Bao W, Li G, Chen C, Han H, Hu S, Yang H (2001) Sequence analysis of the Spodoptera litura multicapsid nucleopolyhedrovirus genome. Virology 287:391-404

Rabindra RJ (1992) Genetic improvement of baculoviruses. In: Ananthkrishnan TN (ed) Emerging trends in biological control of phytophagous insects. Oxford and FBH Publishing Cooperative Private Ltd., New Delhi, pp 183-186

Rabindra RJ, Swamiappan M, Parthasarathy R, Subramanian S, Kennedy JS, Sathiah N, Rajasekaran B (2003) Isolation and DNA characterization of a nuclear polyhedrosis virus from the looper Boarmia (=Ascotis) selenaria (Lepidoptera: Geometridae). Pest Manage Hort Ecosyst 9(1):49-63

Rowley DL, Popham HJR, Harrison RL (2011) Genetic variation and virulence of nucleopolyhedroviruses isolated worldwide from the heliothine pests, Helicoverpa armigera, Helicoverpa zea and Heliothis virescens. J Invertebr Pathol 107:112-126

Shapiro M, Ignoffo CM (1970) Nuclepolyhedrosis of Heliothis: activity of isolates from Heliothis zea. J Invertebr Pathol 16:107-111

Somasekhar S, Jayapragasam M, Rabindra RJ (1993) Characterization of five Indian isolates of the nuclear polyhedrosis virus of $\mathrm{H}$. armigera. Phytoparasitica 21: 333-337

Sudhakar S, Mathavan S (1999) Electron microscopical studies and restriction analysis of Helicoverpa armigera nucleopolyhedrosis virus. J Biosci 24(3):361370

Tamura K, Stecher G, Peterson D, Filipski A, Kumar S (2013) MEGA6: molecular evolutionary genetic analysis version 6.0. Mol Biol Evol 30:2725-2729

Teakle RE, Jensen JM, Giles JE (1986) Age-related susceptibility of Heliothis punctigera to commercial formulation of nuclear polyhedrosis virus. J Invertebr Pathol 47:82-92

Untergasser A, Cutcutache I, Koressaar T, Ye J, Faircloth BC, Remm M, Rozen SG (2012) Primer3 - new capabilities and interfaces. Nucleic Acids Res 40(15): e115 
van Beek NAM, Wood HA, Hughes PR (1988) Quantitative aspects of nuclear polyhedrosis virus infections in lepidopterous larvae: the dose-survival time relationship. J Invertebr Pathol 51:58-63

Whitlock VH (1974) Symptomatology of two viruses infecting Heliothis armigera. J Invertebr Pathol 23:70-75

Williams T, Bergoin M, Van Oers MM (2016) Diversity of large DNA viruses of invertebrates. J Invertebr Pathol 147:4-22

Woo SD (2001) Rapid detection of multiple nucleopolyhedroviruses using polymerase chain reaction. Mol Cell 11(3):334-340

\section{Publisher's Note}

Springer Nature remains neutral with regard to jurisdictional claims in published maps and institutional affiliations.

Submit your manuscript to a SpringerOpen ${ }^{\circ}$ journal and benefit from:

- Convenient online submission

- Rigorous peer review

- Open access: articles freely available online

High visibility within the field

- Retaining the copyright to your article

Submit your next manuscript at $\boldsymbol{\nabla}$ springeropen.com 